\title{
SYNTHESIS AND BIOLOGICAL EVALUATION OF NOVEL THIAZOLE-PYRAZOLE INTEGRATED CHALCONES AS ANTIOXIDANT AND ANTI-INFLAMMATORY AGENTS
}

\author{
DNYANESHWAR SIRSAT ${ }^{1}$, PRADEEP KATE ${ }^{2}$, MADHUSUDAN BACHUTE ${ }^{3 *}$ \\ ${ }^{1}$ Department of Chemistry, Anandibai Raorane Arts, Commerce, and Science College, Vaibhavwadi, Sindhudurg, Maharashtra, India. \\ ${ }^{2}$ Department of Chemistry, Karmaveer Bhaurao Patil Mahavidyalaya, Pandharpur, Solapur, Maharashtra, India. ${ }^{3}$ Department of Chemistry, \\ Sangola College, Sangola, Solapur, Maharashtra, India \\ Email: mbachute@gmail.com \\ Received: 15 May 2019, Revised and Accepted: 10 June 2019
}

\section{ABSTRACT}

Objective: The objective of the present study was to synthesize the thiazole-pyrazole integrated chalcones and their in vitro antioxidant and anti- inflammatory evaluation.

Methods: The designed hybrid thiazole-pyrazole integrated chalcones (3a-j) were synthesized by Claisen-Schmidt reaction of substituted 1-(4-methyl2-phenylthiazol-5-yl) ethanone and substituted pyrazole aldehyde in the presence of $10 \% \mathrm{NaOH}$ in ethanol solvent under reflux condition. The chemical structures of synthesized compounds were confirmed by IR, ${ }^{1} \mathrm{H}$ nuclear magnetic resonance (NMR), ${ }^{13} \mathrm{C}$ NMR, and high- resolution mass spectra.

Results: All the title compounds were screened for their in vitro antioxidant and anti-inflammatory activity. The screening data indicated that tested compounds showed potent antioxidant activity with moderate anti-inflammatory potential.

Conclusion: Antioxidant screening data reveal that most of the synthesized compounds possess excellent 1,1-diphenyl-2-picrylhydrazyl and N0 radical scavenging activity. Most of the compounds found to possess marked anti-inflammatory potential by effectively inhibiting the heat-induced albumin denaturation.

Keywords: Thiazole, Pyrazole, Chalcone, Antioxidant activity, Anti-inflammatory activity.

(C) 2019 The Authors. Published by Innovare Academic Sciences Pvt Ltd. This is an open access article under the CC BY license (http://creativecommons. org/licenses/by/4. 0/) DOI: http://dx.doi.org/10.22159/ajpcr.2019.v12i7.34143

\section{INTRODUCTION}

Chalcones are richly present in nature, source of chalcone starting from ferns to higher plants and some of them are polyhydroxylated in the aryl nucleus [1,2]. Many synthetic methods are reported for the synthesis of chalcones such as Claisen-Schmidt reaction [3], Allan-Robinson condensation (synthesis of flavones through chalcones) [4], Suzuki coupling reaction [5], Ganguly's method (synthesis of flavones through chalcones) [6], Knoevenagel condensation [7], Mukaiyama-type aldol condensation [8], direct cross-coupling reaction [9], chalcone synthesis using boron trifluoride-etherate [10], sonochemical and microwave irradiation technique [11], and grinding technique [12]. The most widely used method is Claisen-Schmidt condensation of ketones and aldehydes.

The presence of thiazole and pyrazole nucleus in different organic structures leads to potent biological activities such as anticancer [13-14], antimicrobial [15-17], anti-inflammatory, and antioxidant [18], antidiabetic [19], and protein kinase inhibitor [20], literature survey reveals that so many of the natural and synthetic thiazole and pyrazole chalcones possess large number of pharmaceutical activities. Due to the importance and in continuation of our work on synthesis of biologically important molecules [21], here, we designed and synthesized various thiazolepyrazole integrated chalcones (Scheme 1).

\section{EXPERIMENTAL SECTION}

Materials and methods

All commercially available chemicals and reagents were purchased from Aldrich and used without further purification. All the solvents were dried and distilled before use. The melting points were determined in open capillary tube and are uncorrected. The IR spectra of synthesized compounds were recorded on Shimadzu 8400-S Fourier-transform infrared spectrophotometer using potassium bromide. The ${ }^{1} \mathrm{H}$ nuclear magnetic resonance (NMR) was recorded in $\mathrm{CDCl}_{3}$ using Bruker $400 \mathrm{MHz}$ NMR spectrometer and chemical shifts are reported as parts per million (ppm) using tetramethylsilane as an internal standard. Reactions were monitored using thin-layer chromatography (TLC) carried out on precoated aluminum plates. The visualization was achieved under ultraviolet light or staining with $\mathrm{I}_{2}$. Chromatographic separations were achieved on silica gel columns (Merck, 60-120 mesh) using gradient of hexane/ethyl acetate as eluent.

General procedure for the preparation of thiazole-pyrazole integrated chalcones

Mixture of substituted 1-(4-methyl-2-phenylthiazol-5-yl)ethanone (1 mmol) (1a-b) and substituted pyrazole aldehyde (1 mmol) (2a-e) was dissolved in $15 \mathrm{ml}$ ethanol. To this reaction, mixture added freshly prepared $1 \mathrm{ml}$ of $10 \%$ sodium hydroxide. The reaction mixture was refluxed at $80-90^{\circ} \mathrm{C}$. The progress of reaction checked by TLC. After completion of the reaction $(1 \mathrm{~h})$, reaction mixture was poured in ice-cold water and stirred for $15 \mathrm{~min}$. The obtained yellow-colored solid was filtered, washed with cold water, and dried. The crude product was recrystallized using ethanol to afford pure titled compound (3a-j).

\section{Spectral data of representative compound}

(E)-1-(4-methyl-2-phenylthiazol-5-yl)-3-(1,3-diphenyl-1H-pyrazol-4-yl) prop-2-en-1-one (3a)

Yellow solid; $73 \%$; M.P. $172-174^{\circ} \mathrm{C}$; IR (KBr): $2922,2852,1742,1650$, $755 \mathrm{~cm}^{-1}$; ${ }^{1} \mathrm{H}$ NMR (400 MHz, $\mathrm{CDCl}_{3}$ ): $\delta=2.823$ (s, 3H, Thy-CH ${ }^{3}$ ), 7.152 


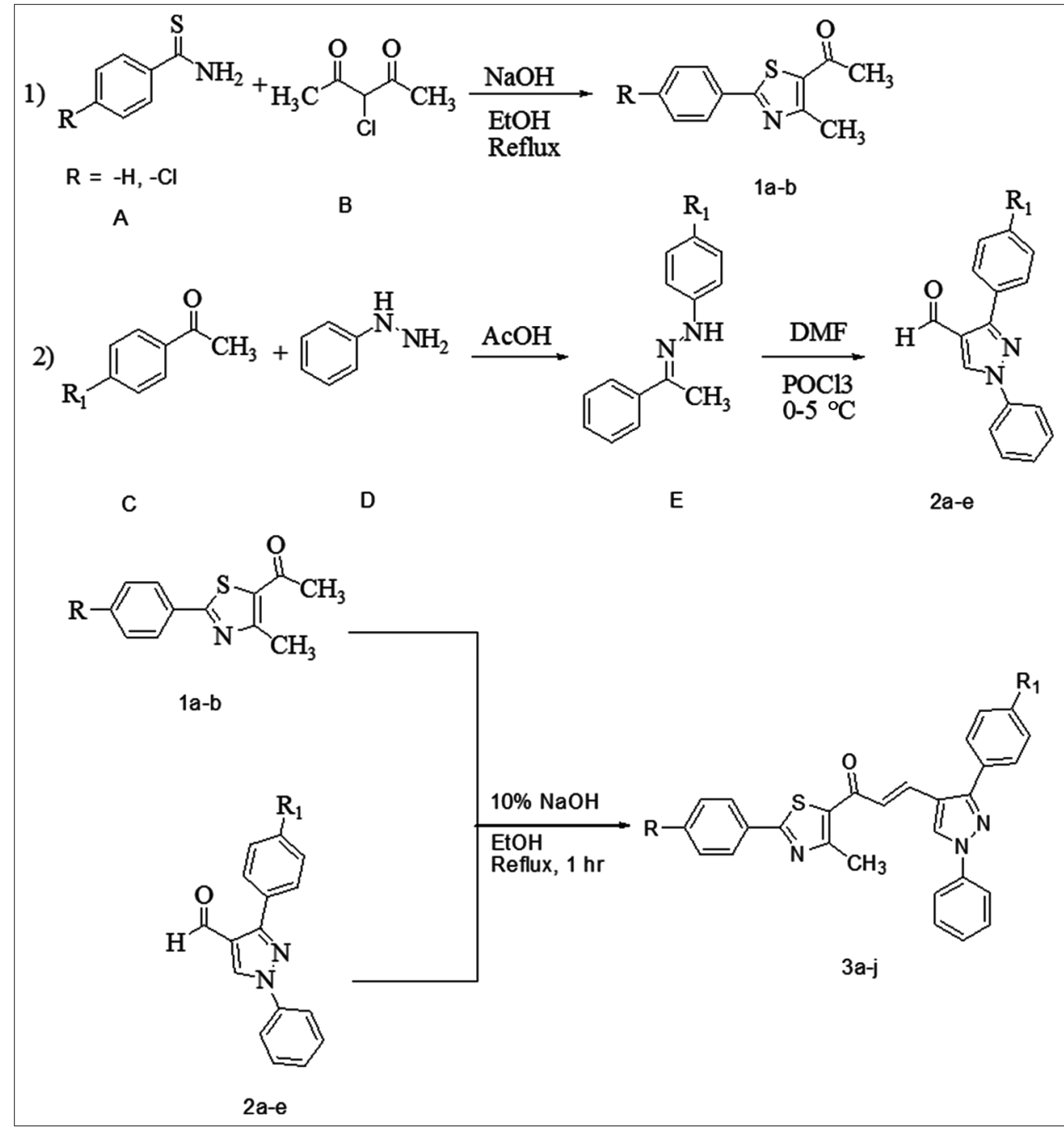

Where,

\begin{tabular}{|c|c|c|}
\hline $\begin{array}{l}\mathbf{3} \mathbf{a ~ R}=\mathrm{H}, \mathrm{R}_{2}=\mathrm{H} \\
\mathbf{3} \mathbf{d ~ R}_{1}=\mathrm{H}, \mathrm{R}_{2}=\mathrm{NO}_{2} \\
\mathbf{3} \mathbf{g ~ R}_{1}=\mathrm{Cl}, \mathrm{R}_{2}=\mathrm{F} \\
\mathbf{3} \mathbf{j ~ R}=\mathrm{Cl}, \mathrm{R}_{2}=\mathrm{OCH}_{3}\end{array}$ & $\begin{array}{l}\text { 3b } \mathrm{R}_{1}=\mathrm{H}, \mathrm{R}_{2}=\mathrm{F} \\
\text { 3e } \mathrm{R}_{1}=\mathrm{H}, \mathrm{R}_{2}=\mathrm{OCH}_{3} \\
\text { 3h } \mathrm{R}_{1}=\mathrm{Cl}, \mathrm{R}_{2}=\mathrm{CH}_{3}\end{array}$ & $\begin{array}{l}\text { 3c R }=\mathrm{H}, \mathrm{R}_{2}=\mathrm{CH}_{3} \\
\text { 3f R R }=\mathrm{Cl} \mathrm{R}=\mathrm{H} \\
\text { 3i R R }_{1}=\mathrm{Cl} \mathrm{R}=\mathrm{NO}_{2}\end{array}$ \\
\hline
\end{tabular}

Scheme 1: Synthesis of thiazole-pyrazole integrated chalcones

(d, 1H, COCH=CH, J=15.2 Hz), 7.376-7.965 (m, 1H, Ar-H), 7.465-7.546 (m, 8H, Ar-H), 7.709-7.733 (m, 2H, Ar-H), 7.813-7.893 (m, 2H, Ar-H), $7.913(\mathrm{~d}, 1 \mathrm{H}, \mathrm{COCH}=\mathrm{CH}, \mathrm{J}=15.2 \mathrm{~Hz}), 7.995-8.019(\mathrm{~m}, 2 \mathrm{H}, \mathrm{Ar}-\mathrm{H}), 8.36$ (s, 1H, Pyr-H); high-resolution mass spectra (HRMS): $\mathrm{m} / \mathrm{z}=448.1469$ $(\mathrm{M}+1) .{ }^{13} \mathrm{C}$ NMR (400 MHz, $\mathrm{CDCl}_{3}, \delta$ in ppm): $18.64\left(\mathrm{~m}\right.$, Thy- $\left.\mathrm{CH}_{3}\right), 117.92$ (m, C), 119.44 (s, C), 123.95 (m, -CH), 126.90 (s, - CH), 127.04 (m, -CH), 127.37 (m, -CH), 128.81 (s, -CH), 128.86 (s, -CH), 129.12 (s, - CH), 129.60 $(\mathrm{m},=\mathrm{CH}), 131.15(\mathrm{w},-\mathrm{CH}), 131.26(\mathrm{~m},-\mathrm{CH}), 132.21(\mathrm{~m},-\mathrm{CH}), 132.89$ (w, C), $135.00(\mathrm{~m}, \mathrm{C}), 139.35(\mathrm{w},=\mathrm{CH}), 154.05(\mathrm{w}, \mathrm{C}), 160.28(\mathrm{w}, \mathrm{C})$, 169.03 (w, C), 182.29 (w, C=0).

(E)-3-(3-(4-fluorophenyl)-1-phenyl-1H-pyrazol-4-yl)-1-(4-methyl-2phenylthiazol-5-yl)prop-2-en-1-one (3b)

Yellow solid; $82 \%$; M.P. $352-354^{\circ} \mathrm{C}$; IR (KBr): 2922, 2852, 1747, $1650,1215,755 \mathrm{~cm}^{-1} ;{ }^{1} \mathrm{H}$ NMR (400 MHz, $\mathrm{CDCl}_{3}$ ): $\delta=2.839$ (s, 3H, Thy$\left.\mathrm{CH}_{3}\right), 7.090(\mathrm{~d}, 1 \mathrm{H}, \mathrm{COCH}=\mathrm{CH}, \mathrm{J}=15.6 \mathrm{~Hz}), 7.196-7.240(\mathrm{~m}, 2 \mathrm{H}, \mathrm{Ar}-\mathrm{H})$, 7.383-7.402 (m, 1H, Ar-H), 7.481-7.543 (m, 5H, Ar-H), 7.682-7.718 $(\mathrm{m}, 2 \mathrm{H}, \mathrm{Ar}-\mathrm{H}), 7.800-7.883(\mathrm{~m}, 2 \mathrm{H}, \mathrm{Ar}-\mathrm{H}$ and $\mathrm{d}, 1 \mathrm{H}, \mathrm{CO}-\mathrm{CH}=\mathrm{CH}$, $\mathrm{J}=15.2 \mathrm{~Hz}$ ), 7.999-8.023 (m, 2H, Ar-H), 8.352 (s, 1H, Pyr-H); HRMS: $\mathrm{m} / \mathrm{z}=466.1373(\mathrm{M}+1)$
(E)-1-(4-methyl-2-phenylthiazol-5-yl)-3-(1-phenyl-3-p-tolyl-1H-pyrazol4-yl)prop-2-en-1-one (Compound 3c)

Yellow solid; $70 \%$; M.P. $204^{\circ} \mathrm{C}$; IR (KBr): 3015, 2918, 1747, 1646, 755; ${ }^{1} \mathrm{H}$ NMR (400 MHz, $\mathrm{CDCl}_{3}$ ): $2.447\left(\mathrm{~s}, 3 \mathrm{H}, \mathrm{Ar}_{-} \mathrm{CH}_{3}\right), 2.821$ (s, 3H, Thy$\mathrm{CH}_{3}$ ), 7.092 (d, $1 \mathrm{H}, \mathrm{CO}-\mathrm{CH}=\mathrm{CH}, \mathrm{J}=15.6 \mathrm{~Hz}$ ), 7.318-7.386 (m, 3H, Ar-H), 7.477-7.533 (m, 5H, Ar-H), 7.596-7.616 (d, 2H, Ar-H), 7.806-7.830 (m, 2H, Ar-H), $7.906(\mathrm{~d}, 1 \mathrm{H}, \mathrm{CO}-\mathrm{CH}=\mathrm{CH}, \mathrm{J}=15.6 \mathrm{~Hz}), 7.997-8.021(\mathrm{~m}$, $2 \mathrm{H}, \mathrm{Ar}-\mathrm{H}), 8.344$ (s, 1H, Pyr-H); HRMS: $\mathrm{m} / \mathrm{z}=462.1628(\mathrm{M}+1) \cdot{ }^{13} \mathrm{C}$ NMR (400 MHz, $\mathrm{CDCl}_{3}, \delta$ in ppm): $18.61\left(\mathrm{~m}, \mathrm{Thy}-\mathrm{CH}_{3}\right), 21.39\left(\mathrm{~m}, \mathrm{Ar}_{-} \mathrm{CH}_{3}\right)$, 117.89 (m, C), 119.10 (w, C), 119.43 (s, -CH), 123.81 (m, -CH), 126.89 $(\mathrm{s},-\mathrm{CH}), 126.96(\mathrm{~s},-\mathrm{CH}), 127.29(\mathrm{~s},-\mathrm{CH}), 128.73(\mathrm{~s},-\mathrm{CH}), 128.97(\mathrm{~s},-\mathrm{CH})$, 129.11 (s, -CH), 129.30 (s, -CH), 129.40 (s, -CH), 129.55 (m, -CH), $129.58(\mathrm{~s},=\mathrm{CH}), 131.13(\mathrm{~s},-\mathrm{CH}), 131.33(\mathrm{~m}, \mathrm{C}), 132.91(\mathrm{~m}, \mathrm{C}), 135.19$ (m, C), 138.73 (m, C), 139.39 (m, =CH), 154.14 (w, C), $160.18(\mathrm{~m}, \mathrm{C})$, $169.00(\mathrm{~m}, \mathrm{C}), 182.33(\mathrm{~m}, \mathrm{C}=0)$.

(E)-3-(3-(4-methoxyphenyl)-1-phenyl-1H-pyrazol-4-yl)-1-(4-methyl-2phenylthiazol-5-yl)prop-2-en-1-one (Compound 3e)

Yellow solid; $80.50 \%$; M.P. $176^{\circ} \mathrm{C}$; IR (KBr): 2922, 2852, 1744 , 1651, 1240, $757{ }^{1} \mathrm{H}$ NMR (400 MHz, $\mathrm{CDCl}_{3}$ ): 2.830 (s, 3H, Ar- $\mathrm{CH}_{3}$ ), 
3.884 (s, 3H, Ar- $-\mathrm{OCH}_{3}$ ), 7.029-7.058 (m, 3H, Ar-H), 7.086 (d, 1H, CO$\mathrm{CH}=\mathrm{CH}, \mathrm{J}=15.6 \mathrm{~Hz}), 7.344-7.528(\mathrm{~m}, 5 \mathrm{H}, \mathrm{Ar}-\mathrm{H}), 7.637-7.659(\mathrm{~m}, 2 \mathrm{H}$, Ar-H), 7.799-7.823 (m, 2H, Ar-H), 7.896 (d, $1 \mathrm{H}, \mathrm{CO}-\mathrm{CH}=\mathrm{CH}, \mathrm{J}=15.6 \mathrm{~Hz}$ ), 7.955-8.020 (m, 2H, Ar-H), 8.334 (s, 1H, Pyr-H); HRMS: $\mathrm{m} / \mathrm{z}=478.1576$ $(\mathrm{M}+1) \cdot{ }^{13} \mathrm{C}$ NMR $\left(400 \mathrm{MHz}, \mathrm{CDCl}_{3}, \delta\right.$ in ppm): $18.64\left(\mathrm{~m}, \mathrm{Thy}^{-\mathrm{CH}_{3}}\right), 55.39$ (m, Ar-OCH $\left.)_{3}\right), 114.32$ (s, C), 117.76 (m, C), 119.39 (s, - CH), 123.75 (m, -CH), 124.67 (s, -CH), 126.90 (m, C), 126.94 (m, -CH), 127.27 (s, -CH), 129.12 (s, - CH), 129.58 (s, =CH), $130.11(\mathrm{~s},-\mathrm{CH}), 131.14(\mathrm{~s},-\mathrm{CH}), 131.27$ (s, -CH), 132.89 (m, C), 135.22 (m, C), 139.38 (m, =CH), 153.89 (m, C), 160.15 (m, C), 160.24 (m, C), 168.99 (w, C), 182.31 (m, C=0).

(E)-1-(2-(4-chlorophenyl)-4-methylthiazol-5-yl)-3-(1,3-diphenyl-1Hpyrazol-4-yl)prop-2-en-1-one (Compound 3f)

Yellow solid; $67.00 \%$; M.P. $186^{\circ} \mathrm{C}-188^{\circ} \mathrm{C}$; IR (KBr): $3007,2925,1748$, 1659, 755, 700; ${ }^{1} \mathrm{H}$ NMR (400 MHz, $\mathrm{CDCl}_{3}$ ): 2.804 (s, 3H, Thy-H), 7.081 (d, $1 \mathrm{H}, \mathrm{CO}-\mathrm{CH}=\mathrm{CH}, \mathrm{J}=15.2 \mathrm{~Hz}$ ), 7.377-7.446 (m, 1H, Ar-H), 7.457-7.538 (m, 8H, Ar-H), 7.703-7.727 (m, 2H, Ar-H), 7.808-7.832 (m, 2H, Ar-H), 7.891-7.948 (m, 1H, Ar-H and d, $1 \mathrm{H}, \mathrm{CO}-\mathrm{CH}=\mathrm{CH}, \mathrm{J}=15.2 \mathrm{~Hz}), 8.351$ (s, 1H, Pyr-H); HRMS: m/z=482.1087 (M+1)

(E)-1-(2-(4-chlorophenyl)-4-methylthiazol-5-yl)-3-(3-(4-fluorophenyl)1-phenyl-1H-pyrazol-4-yl)prop-2-en-1-one (Compound 3g)

Yellow Solid; Yield: $87.01 \%$; M.P. $192^{\circ} \mathrm{C}$; IR (KBr): 3048, 2927, 1749, 1653, 1209, 745, 700; ${ }^{1} \mathrm{H}$ NMR (400 MHz, $\mathrm{CDCl}_{3}$ ): 2.823 (s, 3H, Thy$\left.\mathrm{CH}_{3}\right), 7.068$ (d, $\left.1 \mathrm{H}, \mathrm{CO}-\mathrm{CH}=\mathrm{CH}, \mathrm{J}=15.2 \mathrm{~Hz}\right), 7.194-7.238(\mathrm{~m}, 3 \mathrm{H}, \mathrm{Ar}-\mathrm{H})$, 7.385-7.403 (m, 1H, Ar-H), 7.445-7.467 (m, 2H, Ar-H), 7.503-7.542 (m, 2H, Ar-H), 7.676-7.711 (m, 2H, Ar-H), 7.795-7.882 (m, 1H, $\mathrm{Ar}-\mathrm{H}$ and d, $1 \mathrm{H}, \mathrm{CO}-\mathrm{CH}=\mathrm{CH}, \mathrm{J}=15.6 \mathrm{~Hz}), 7.932-7.953(\mathrm{~m}, 2 \mathrm{H}, \mathrm{Ar}-\mathrm{H})$, 8.345 (s, 1H, Pyr-H); HRMS: m/z=500.0997 (M+1)

(E)-1-(2-(4-chlorophenyl)-4-methylthiazol-5-yl)-3-(1-phenyl-3-p-tolyl1H-pyrazol-4-yl)prop-2-en-1-one (Compound 3h)

Yellow Solid; Yield: $78.11 \%$; M.P. $184^{\circ} \mathrm{C}$; IR (KBr): 3121, 2919, 1751 , 1656, 754, 700; ${ }^{1} \mathrm{H}$ NMR (400 MHz, $\mathrm{CDCl}_{3}$ ): 2.443 (s, 3H, $\mathrm{Ar}^{-\mathrm{CH}_{3}}$ ), 2.788 (s, 3H, Thy-CH $), 7.066$ (d, $1 \mathrm{H}, \mathrm{CO}-\mathrm{CH}=\mathrm{CH}, \mathrm{J}=15.6 \mathrm{~Hz}$ ), 7.312-7.384 (m, 3H, Ar-H), 7.427-7.464 (m, 3H, Ar-H), 7.489-7.529 (m, 2H, Ar-H), 7.588-7.608 (m, 2H, Ar-H), 7.800-7.880 (m, 2H, Ar-H), 7.913-7.952 (m, $1 \mathrm{H}, \mathrm{Ar}-\mathrm{H}$ and d, $1 \mathrm{H}, \mathrm{CO}-\mathrm{CH}=\mathrm{CH}, \mathrm{J}=15.2 \mathrm{~Hz}), 8.332(\mathrm{~s}, 1 \mathrm{H}, \mathrm{Pyr}-\mathrm{H})$; HRMS: $\mathrm{m} / \mathrm{z}=496.1250(\mathrm{M}+) \cdot{ }^{13} \mathrm{C}$ NMR $\left(400 \mathrm{MHz}, \mathrm{CDCl}_{3}, \delta\right.$ in ppm): 18.56 (m, Thy- $\left.\mathrm{CH}_{3}\right), 21.39$ (m, Ar- $\left.\mathrm{CH}_{3}\right), 117.83$ (m, C), 119.41 (s, C), 123.59 (s, -CH), 126.98 (s, -CH), 127.32 (s, CH), 128.05 (s, -CH), 128.08 (s, -CH), 128.73 (s, -CH), 129.28 (s, -CH), 129.37 (s, -CH), 129.55 (s, -CH), 129.59 (s, =CH), 131.39 (s, -CH), 131.67 (m, C), 135.39 (m, C), 137.19 $(\mathrm{m}, \mathrm{C}), 138.75(\mathrm{~m}, \mathrm{C}), 139.36(\mathrm{~m},=\mathrm{CH}), 154.15(\mathrm{~m}, \mathrm{C}), 160.13(\mathrm{~m}, \mathrm{C})$, $167.51(\mathrm{~m}, \mathrm{C}), 182.20(\mathrm{~m}, \mathrm{C}=0)$.

(E) -1-(2-(4-chlorophenyl)-4-methylthiazol-5-yl)-3-(3-(4methoxyphenyl)-1-phenyl-1H-pyrazol-4-

(Compound 3j)

yl)prop-2-en-1-one

Yellow Solid; Yield: $76.32 \%$; M.P. $176^{\circ} \mathrm{C}$; IR (KBr): $3113,2926,1743$, 1656, 1233, 754, 700; ${ }^{1} \mathrm{H}$ NMR (400 MHz, $\mathrm{CDCl}_{3}$ ): 2.813 (s, 3H, Thy-H), 3.885 (s, 3H, AR- $\left.-\mathrm{OCH}_{3}\right), 7.034-7.084(\mathrm{~m}, 2 \mathrm{H}, \mathrm{Ar}-\mathrm{H}$ and d, $1 \mathrm{H}, \mathrm{CO}-\mathrm{CH}=\mathrm{CH}$, $\mathrm{J}=15.6 \mathrm{~Hz}), 7.365-7.383$ (m, 1H, Ar-H), 7.437-7.459 (m, 2H, Ar-H), 7.489-7.529 (m, 2H, Ar-H), 7.631-7.655 (m, 2H, Ar-H), 7.795-7.819 $(\mathrm{m}, 2 \mathrm{H}, \mathrm{Ar}-\mathrm{H}), 7.895(\mathrm{~d}, 1 \mathrm{H}, \mathrm{CO}-\mathrm{CH}=\mathrm{CH}, \mathrm{J}=15.2 \mathrm{~Hz}), 7.927-7.949(\mathrm{~m}, 2 \mathrm{H}$, Ar-H), 8.327 (s,1H, Pyr-H); HRMS: m/z=512.1196 (M+).

\section{Biological activity}

In vitro anti-inflammatory activity by protein denaturation method

The reaction mixture $(2.5 \mathrm{~mL}$ ) consisted of $0.1 \mathrm{~mL}$ of egg albumin (from fresh hen's egg), $1.4 \mathrm{~mL}$ of phosphate-buffered saline (PBS, pH 6.4) and $1 \mathrm{~mL}$ of synthetic derivatives $(1 \mathrm{mM})$. Similar volume of PBS served as control. Then, the mixtures were incubated at $37^{\circ} \mathrm{C} \pm 2$ in an incubator for $15 \mathrm{~min}$ and then heated at $70^{\circ} \mathrm{C}$ for $5 \mathrm{~min}$. After cooling, their absorbance was measured at $660 \mathrm{~nm}$ using vehicle as blank. Diclofenac sodium at $1 \mathrm{mM}$ was used as reference drug and treated similarly for the determination of absorbance. The percentage inhibition of protein
Table 1: Anti-inflammatory and antioxidant activity of synthesized compound (3a-j)

\begin{tabular}{|c|c|c|c|c|c|}
\hline \multirow[t]{2}{*}{$\begin{array}{l}\text { Compound } \\
\text { No./Code }\end{array}$} & \multirow{2}{*}{$\begin{array}{l}\text { Anti-inflammatory } \\
\text { activity } \% \\
\text { inhibition at } 1 \mathrm{mM}\end{array}$} & \multicolumn{4}{|c|}{$\begin{array}{l}\text { Antioxidant activity \% } \\
\text { inhibition at } 1 \mathrm{mM} / \mathrm{mL}\end{array}$} \\
\hline & & DPPH & $\mathbf{H}_{2} \mathbf{O}_{2}$ & NO & SOR \\
\hline $3 a$ & 52 & 25.07 & 20.33 & 18.27 & 15.18 \\
\hline $3 b$ & 58 & 25.58 & 21.78 & 51.90 & 22.47 \\
\hline $3 c$ & 71 & 40.98 & 37.50 & 19.82 & 16.88 \\
\hline $3 d$ & 45 & 32.72 & 23.96 & 23.80 & 20.25 \\
\hline $3 e$ & 80 & 45.21 & 39.45 & 48.75 & 23.10 \\
\hline $3 f$ & 62 & 39.87 & 25.66 & 26.40 & 15.54 \\
\hline $3 g$ & 59 & 29.44 & 22.37 & 58.25 & 26.78 \\
\hline $3 \mathrm{~h}$ & 74 & 41.69 & 35.81 & 22.57 & 18.05 \\
\hline $3 \mathbf{i}$ & 50 & 47.36 & 40.39 & 20.15 & 21.55 \\
\hline $3 \mathbf{j}$ & 86 & 48.05 & 43.60 & 55.12 & 25.90 \\
\hline $\begin{array}{l}\text { Diclofenac } \\
\text { sodium }\end{array}$ & 90.21 & - & - & - & - \\
\hline $\begin{array}{l}\text { Ascorbic } \\
\text { acid }\end{array}$ & - & 42.98 & & 42.63 & 89.13 \\
\hline $\mathrm{BHT}$ & - & - & 88.42 & - & - \\
\hline
\end{tabular}

BHT: Butylated hydroxytoluene

denaturation was calculated using the following formula and results recorded in Table 1.

$\%$ inhibition $=100 \times(\mathrm{Vt} / \mathrm{Vc}-1)$

Where, $\mathrm{Vt}=$ absorbance of test sample and $\mathrm{Vc}=$ absorbance of control

\section{1,1-diphenyl-2-picrylhydrazyl (DPPH) scavenging activity}

The molecule DPPH is characterized as a stable free radical by virtue of the delocalization of the spare electron over the molecule as a whole so that the molecule does not dimerize, as would be the case with most other free radicals. The delocalization of electron also gives progress to the deep violet color, characterized by an absorption band in ethanolic solution at about $517 \mathrm{~nm}$. When a solution of DPPH is mixed with that of a substrate $(\mathrm{AH})$ that can donate a hydrogen atom, then this gives rise to the reduced form with the loss of this violet color. To evaluate the antioxidant potential through free radical scavenging by the test samples, the change in optical density of DPPH radicals is monitored and results recorded in Table 1.

\section{Hydrogen peroxide scavenging $\left(\mathrm{H}_{2} \mathrm{O}_{2}\right)$ activity}

Human beings are exposed to $\mathrm{H}_{2} \mathrm{O}_{2}$ indirectly through the environment nearly about $0.28 \mathrm{mg} / \mathrm{kg} /$ day with intake mostly from leaf crops. Hydrogen peroxide may enter the human body through inhalation of vapor or mist and through eye or skin contact. $\mathrm{H}_{2} \mathrm{O}_{2}$ is rapidly decomposed into oxygen and water and this may produce hydroxyl radicals that can initiate lipid per oxidation and cause DNA damage in the body and results recorded in Table 1 .

\section{Nitric oxide (NO) scavenging activity}

NO is formed in biological tissues by specific NO synthases, which metabolizes arginine to citrulline with the formation of NO through a five electron oxidative reaction. The sodium nitroprusside is known to decompose in aqueous solution at physiological $\mathrm{pH}$ (7.2) producing NO. Under aerobic conditions, NO reacts with oxygen to produce stable products (nitrate and nitrite), the quantities of which can be determined using Griess reagent and results recorded in Table 1.

Superoxide radical (SOR) scavenging assay

SOR radical scavenging activity was carried out as per the reported method. The mixture consisting of $1 \mathrm{~mL}$ of nitro blue tetrazolium (NBT) solution (156 mM NBT in phosphate buffer, $\mathrm{pH}$ 7.4), 1 mL NADH solution (468 mM NADH in phosphate buffer, $\mathrm{pH}$ 7.4), and $1 \mathrm{~mL}$ of synthetic compound $(1 \mathrm{mM})$ solution was mixed. The reaction was started by adding $1 \mathrm{~mL}$ of phenazinemethosulfate (PMS) solution (60 mM PMS in 
phosphate buffer, $\mathrm{pH} 7.4$ ) to the above mixture. The reaction mixture was incubated for 5 minutes at $250 \mathrm{C}$ and the absorbance was measured at $560 \mathrm{~nm}$ against blank sample and compared with standards and percentage inhibition was calculated using the same formula as above. Decreased absorbance indicates increased SOR scavenging activity.

\section{RESULTS AND DISCUSSION}

\section{Chemistry}

Synthesis of thiazole-pyrazole integrated chalcones (3a-j) was achieved by Claisen-Schmidt reaction of substituted 1-(4-methyl-2phenylthiazol-5-yl) ethanone and substituted pyrazole aldehyde in the presence of $10 \% \mathrm{NaOH}$ in ethyl alcohol as a solvent under reflux condition. The synthesis of substituted pyrazole aldehydes was achieved as per the procedure reported in literature [22]. The chemical structures of synthesized compounds were confirmed by IR, ${ }^{1} \mathrm{H}$ NMR, and HRMS data.

\section{Biological evaluation \\ Anti-inflammatory activity}

Denaturation of proteins is a well-established cause of inflammation. In the present work, the in vitro anti-inflammatory potential of synthesized thiazole-pyrazole integrated chalcones was evaluated against denaturation of egg albumin and the results are illustrated in Table 1. Most of the compounds were found to have significant antiinflammatory properties. Compound $\mathbf{3 j}, \mathbf{3 e}, \mathbf{3 h}$, and $\mathbf{3} \mathbf{c}$ exhibited significant inhibition of protein denaturation compared to the reference standard diclofenac sodium, a standard anti-inflammatory drug at 1 mM concentration; however, compound $\mathbf{3 f}, \mathbf{3 g}$, and $\mathbf{3 b}$ showed good inhibition. On the other hand, all other compounds were also found to possess moderate inhibition of heat-induced egg albumin denaturation.

\section{Antioxidant activity}

Reactive oxygen species (ROS) and nitrogen species are responsible to the pathophysiology of anti-inflammatory conditions. Taking into the consideration of multifactorial character of oxidative stress which is involved in several pathological states, we have further evaluated antioxidant properties of synthesized compounds $\mathbf{3} \mathbf{a}-\mathbf{j}$ for their antioxidant potential against ROS such as DPPH, $\mathrm{H}_{2} \mathrm{O}_{2}$, NO, and SOR radicals compared to reference standard ascorbic acid and the results are listed in Table 1. All the synthesized compounds demonstrated good to moderate scavenging activity against DPPH and NO radicals, whereas moderate to weak activity against $\mathrm{H}_{2} \mathrm{O}_{2}$ and SOR radicals. The antioxidant activity results revealed that the compounds $3 \mathbf{j}, \mathbf{3 i}$, $\mathbf{3 e}, \mathbf{3 h}$, and $\mathbf{3 c}$ were found to possess significant inhibition of DPPH radical scavenging activity. On the other hand, all other compounds were found to be moderate scavengers of DPPH radical. Compound $\mathbf{3 g}, \mathbf{3} \mathbf{j}$, and $\mathbf{3} \mathbf{b}$ exhibited significant inhibition of NO radicals compared to the standard drug ascorbic acid. However, remaining compounds were moderate NO radical scavengers compared to ascorbic acid. On the other hand, all the compounds were unveiled moderate to weak inhibition of peroxide $\left(\mathrm{H}_{2} \mathrm{O}_{2}\right)$ and superoxide (SOR) radicals compared to reference drug butylated hydroxytoluene and ascorbic acid, respectively.

\section{CONCLUSION}

All the newly synthesized compounds were confirmed by IR, ${ }^{1} \mathrm{H}$ NMR, and HRMS. In vitro antioxidant screening data of newly synthesized compounds revealed that most of the synthesized compounds possess excellent DPPH and NO radical scavenging activity. All the compounds found to possess marked anti-inflammatory potential by effectively inhibiting the heat-induced albumin denaturation. Further, bioassay, optimization, and structure-activity relationship of the title compounds are underway.

\section{ACKNOWLEDGMENTS}

The authors are thankful to Principal, Karmaveer Bhaurao Patil Mahavidyalaya, Pandharpur, Dist. - Solapur, Maharashtra, India, as well as authors are thankful to Principal, Anandibai Raorane Arts, Commerce, and Science College, Vaibhavwadi, Dist. - Sindhudurg, Maharashtra, India, for providing laboratory facilities.

\section{AUTHORS' CONTRIBUTIONS}

Dnyaneshwar M Sirsat carried out experimental work, spectral characterization, biological evaluation, and wrote this article. Madhusudan T Bachute provided guidance for writing this article as well as provided guidance for crucial review and revision. Pradeep R Kate encouraged Dnyaneshwar M Sirsat to explore the finding of work.

\section{CONFLICTS OF INTEREST}

The authors declare that they have no conflicts of interest.

\section{REFERENCES}

1. Khatib S, Nerya O, Musa R, Shmuel A, Tamir S, Vaya J. Chalcones as potent tyrosinase inhibitors: The importance of a 2,4-substituted resorcinol moiety. Bioorg Med Chem 2005;13:433-41.

2. Chavan HV, Bandgar BP, Adsul LK, Dhakane VD, Bhale PS, Thakare VN, et al. Design, synthesis, characterization and anti- inflammatory evaluationof novel pyrazole amalgamated flavones. Bioorg Med Chem Lett 2013;23:1315-21.

3. Climent MJ, Corma A, Iborra S, Velty A. Activated hydrotalcites as catalysts for the synthesis of chalcones of pharmaceutical interest. J Catal 2004;221:474-82.

4. Fukui K, Matsumoto T, Nakamura S, Nakayama M. Synthetic studies of the flavone derivatives. VII. The synthesis of jaceidin. Bull Chem Soc Jpn 1968;41:1413-7.

5. Eddarir S, Cotelle N, Bakkour Y, Rolando C. An efficient synthesis of chalcones based on the Suzuki reaction. Tetrahedron Lett 2003;44:5359-63.

6. Ganguly AK, Kaur S, Mahata PK, Biswas D, Pramanik BN, Chan TM. Synthesis and properties of 3-acyl-_-pyrones, a novel class of flavones and chromones. Tetrahedron Lett 2005;46:4119- 21.

7. Bhale PS, Chavan HV, Dongare SB, Shringare SN, Mule YB, Nagane SS, et al. Synthesis of extended conjugated indolyl chalcones as potent anti-breast cancer, anti-inflammatory and antioxidant agents. Bioorg Med Chem Lett 2017;27:1502-7.

8. Honda $\mathrm{T}$, Yoshizawa $\mathrm{H}$, Sundararajan C, David E, Lajoie MJ, Favaloro FG Jr., et al. Tricyclic compounds containing nonenolizable cyano enones. A novel class of highly potent anti-inflammatory and cytoprotective agents. J Med Chem 2011;54:1762-78.

9. Al-Masum M, Ng E, Wai MC. Palladium-catalyzed direct cross-coupling of potassium styryltrifluoroborates and benzoyl chlorides-a one-step method for chalcone synthesis. Tetrahedron Lett 2011;52:1008-10.

10. Narender T, Papi Reddy K. A simple and highly efficient method for the synthesis of chalcones by using borontrifluoride-etherate. Tetrahedron Lett 2007;48:3177-80.

11. Srivastava YK. Ecofriendly microwave assisted synthesis of some chalcones. Rasa J Chem 2008;1:884-6.

12. Zangade S, Mokle S, Vibhute A, Vibhute Y. An efficient and operationally simple synthesis of some new chalcones by using grinding. Tech Chem Sci J 2011;2:1-6.

13. Ayati A, Esmaeili R, Moghimi S, Oghabi Bakhshaiesh T, Eslami-S Z, Majidzadeh-A K, et al. Synthesis and biological evaluation of 4-amino-5-cinnamoylthiazoles as chalcone-like anticancer agents. Eur J Med Chem 2018;145:404-12.

14. (a) Rai US, Isloor AM, Shetty P, Pai HK, Fun HK. Synthesis and in vitro biological evaluation of new pyrazole chalcones and heterocyclic diamides as potential anticancer agents. Arab J Chem 2015;8:317-21. (b) Bekhit AA, Haimanot T, Hymete A. Evaluation of some $1 \mathrm{H}$-pyrazole derivatives as a dual acting antimalarial and antileishmanial agents. Pak J Pharm Sci 2014;27:1767-73.

15. Alsarahni A, Muhi-Eldeen Z, Al-Kaissi E, Al-Adham I, Al-Muhtase N. Synthesisandstructuralelucidationofaminoacetylenicandthiocarbamates derivatives for 2-mercaptobenzothiazole as antimicrobial agents. Int J Pharm Pharm Sci 2017;9:192-7.

16. Pisal P, Deodhar M, Kale A, Nigade G, Pawar S. Design, synthesis, docking studies and biological evaluation of 2-phenyl-3-(substituted benzo[d] thiazol-2-ylamino)-quinazoline-4(3h)-one derivatives as antimicrobial agents. Int J Pharm Pharm Sci 2018;10:57-61.

17. Sashidhara KV, Rao KB, Kushwaha P, Modukuri RK, Singh P, Soni I, et al. Novel chalcone-thiazole hybrids as potent inhibitors of drug 
resistant Staphylococcus aureus. ACS Med Chem Lett 2015;6:809-13.

18. Jadhav SY, Bhosale RB, Shirame SP, Hublikar MG, Sonawane KD, Shaikh RV. Synthesis and biological evaluation of fluoro-hydroxy submitted pyrazolechalcones as anti-inflammatory antioxidant and antibacterial agents. Int J Pharm Biosci 2013;4:390-7.

19. Sunil K, Rathore DS, Garg G, Khatri K, Saxena R, Sanjeev KS. Synthesis and evaluation of some benzothiazole derivatives as antidiabetic agents. Int J Pharm Pharm Sci 2017;9:60-8.

20. Sivakumar D, Geetha G, Molecular docking studies on thiadiazole derivatives as protein kinase inhibitors. Int J Pharm Pharm Sci 2018; $10: 70-4$

21. Bhale PS, Bandgar BP, Dongare SB, Shringare SN, Sirsat DM, Chavan HV. Ketene dithioacetal mediated synthesis of 1,3,4,5-tetrasubstituted pyrazolederivativesand their biological evaluation. Phosphorus Sulfur Silicon Relat Elem 2019:1-7. [doi: 10.1080/10426507.2019.1565760].

22. Liaras K, Geronikaki A, Glamočlija J, Cirić A, Soković M. Thiazolebased chalcones as potent antimicrobial agents. Synthesis and biological evaluation. Bioorg Med Chem 2011;19:3135-40. 